\title{
Evaluation and future options for hillock crop production system in Lalmai region of Bangladesh
}

\author{
Khokan Kumer Sarker ${ }^{1}$, Md. Ashraful Alam², Mohammad Kamrul Hasan ${ }^{3}$, \\ Mohammad Raziul Hassan Mondol ${ }^{4}$ \\ ${ }^{1}$ Irrigation and Water Management (IWM) Division, Bangladesh Agricultural Research Institute (BARI), Gazipur, 1701, Bangladesh \\ ${ }^{2}$ Wheat Research Centre, BARI, Nashipur, Dinajpur, Bangladesh \\ ${ }^{3}$ Bangladesh Academy for Rural Development (BARD), Comilla, Bangladesh \\ ${ }^{4}$ Pulses Research Centre, Regional Agricultural Research Station, BARI, Jessore, Bangladesh \\ Email address: \\ ksarkerwrc@gmail.com (K. K. Sarker), ashrafulw@yahoo.com (M.A. Alam), hasan.kamrul17@yahoo.com (M. K. Hasan), \\ raziulh@ymail.com (M.R.H. Mondol)
}

\section{To cite this article:}

Khokan Kumer Sarker, Md. Ashraful Alam, Mohammad Kamrul Hasan, Mohammad Raziul Hassan Mondol. Evaluation and Future Options for Hillock Crop Production System in Lalmai Region of Bangladesh. Agriculture, Forestry and Fisheries.

Vol. 3, No. 4, 2014, pp. 313-319. doi: 10.11648/j.aff.20140304.24

\begin{abstract}
Lalmai hillock area is emerging as one of the prominent vegetable growing areas of Bangladesh. The study was undertaken to evaluate the existing cropping patterns, economic analysis, identify general problems and develop future options for improving hillock crop production systems in the Lalmai hillock areas of Comilla region in Bangladesh. The study was concentrated in three villages of Lalmai hillock region of the Comilla district. Data were collected on 33 respondents of those three villages by interview schedule with the help of scientists as well as research personnel. The obtained findings indicated that most of the farmers practiced fallow-country bean cropping sequences on the top of hillock during kharif season. The benefit cost ratio (BCR) of the bottle gourd was observed higher than other existing crops. BCR of the cucumber, turmeric and long bean was observed almost similar. BCR of the existing cropping pattern per year in the study area was counted from the range of 1.43 to 1.95 . BCR was found higher in the cropping pattern of fallow + bitter gourd + country bean than other existing cropping pattern of the study area. The lowest BCR was observed from the one crop per year. Unit production cost of the potato was lowest as compared to other crops. Vegetable cultivation with relay cropping method is the most economical viable cropping pattern. The consecutive crops are country bean + bottle gourd and country bean + matos and BCR was found 2.29 and 1.96, respectively. Overhead tank system tubewell and rainwater harvesting systems could be provided at the hillock areas for irrigation in order to increase the crop productivity. Drought resistance crops and crops requiring light irrigation are suggested for crop production of the hillock region during winter season. However, proper implementation of the crop production system may help to bring the positive changes in the economy of the country.
\end{abstract}

Keywords: Hill Agriculture, Cropping Pattern, Relay Crops, Strategy Development

\section{Introduction}

Agriculture is the foundation of national economy. Economic development means agricultural development (1). Sustainable agriculture is the main aptitude and a necessary long term task of the world agriculture. Sustainable agriculture and economy should be the main economy part of the general strategy of sustainable development in the $21^{\text {st }}$ century. The cultivated area is about 8.4 million hectare which is $56.6 \%$ of the total land area is practiced for food crops production (2). Mainly flood plain occupies almost
$80 \%$ of the land area, Hill area is about $12 \%$ and Terrace area $8 \%$ which are contributing the agriculture to gross domestic product (3). Bangladesh faces acute scarcity of land and continues to remain under pressure of huge population. Since Bangladesh is facing a chronic vegetables shortage with excessive pressure of population on limited land on one hand and supply of limited water resources on the other, therefore, the government have realized that population-food balance in the country would only be attainable through technological progress, namely, through adoption of modern varieties, seed-fertilizer-irrigation 
technologies and marketing systems.

Crop production is the main source of income for farmers at hillock region in Lalmai. Important crops that are grown include bottle gourd, country bean, long bean, tao, banana, turmeric, ginger, \& various fruit and wood trees. The hillocks are not continuous in nature, and often disrupted by human habits. Only few hillock tops are fairly level. The average elevation is 12.18 meter above the plains and 27.42 meter above sea level (4). In such situation, study on hillock agriculture development is very important. The hills of Bangladesh are highly fertile and productive. It is quite natural that people extract resources from hilly lands for their survival. The Lalmai hillocks, although covering a small area, have been contributing substantially to the agriculture dominant economy of Comilla sadar upazila. With increasing population, it is necessary to find out the way of alternative to utilize the limited natural resources in the best possible ways for appropriate plans and their successful implementation. There is no overall plan to prevent the soil erosion on a regional scale. Soil erosion is severe in this region where land is used beyond its capacity and method of soil as well as crop management that are ecologically incompatible.

Water is the single most binding constraint to agriculture in hill and hillock areas. Surface and groundwater sources are still oppressed. Water management may play a central role in climate adaptation. Water extraction rates are mostly unsustainable due to continue to fall the groundwater levels. In some cases, water is inefficiently used and thus is subject to huge losses in both domestic and agricultural sectors. Most irrigation systems are less. Farmers who get water free or for little cost have no incentive to reduce their usage with water-saving technologies. Climate change may also increase risk, because extreme events (droughts, floods, temperature spikes) are predicted to increase in frequency and magnitude. Greater variability will compound the problems of hill areas, where variability is already high. Declines in rainfall will directly hamper the production, and necessitate changes in cropping patterns, and agricultural production. The conventional farming and non-adoption of recommended technologies are also causes in agriculture crop production. The improved practice with different cropping systems is an excellent approach for sustainable production, income generation and employment opportunity of the small and marginal rural households in hilly regions (5). The improved farming system gave higher net return and benefit cost ratio to the farmers as compared to traditional farming (6).

Bangladesh government has drawn attention on the impact of agriculture in hill areas from different angles and dimension. The integrated hill farming systems approach is necessary for development the technologies that are compatible with the environment, bio-physically sound, economically viable and socially acceptable (2). Development of hillock agriculture system may increase the proper utilization of hillock land which may protect the soil surface and crop from strong wind damage. There is no wide range of research findings and guidelines on agriculture systems in the Lalmai region of Comilla, and experimental evidence on hillock crop production systems is still scarcely reported in well documentations. Therefore, this study is the most important from the economic point of view as well as soil and water management. Findings and learning of this study may help to recommend actions for the protection and development of agriculture cropping systems with economically and environment friendly in the hillock regions of Lalmai of the Comilla. With this in view, to address the solved crop production system in the hillock areas for the long term sustainability, the specific objectives were (i) to evaluate the cropping patterns of the hillock crop production system; (ii) to assess the economic analysis of crop production systems, and (iii) to identify general problems and develop future options for improving hillock crop production systems at the Lalmai region of Comilla district in Bangladesh.

\section{Materials and Methods}

The study was carried out at Lalmai region of Comilla during the year of 2013-2014. The soil of Lalmai is well drained and loose in nature. It has low fertility. Strongly acid-brown soils occur on gently rolling and steep. The yellowish brown topsoil overlying yellowish red structure clay sub soil. The acid brown hillock soils that occupy most of the northern and eastern hill areas are strongly acidic, dominated by oxides and aluminum and are generally of low fertility with restricted root growth because of low levels of calcium, magnesium and potassium. Other constraints in these soils include inaccessibility due to steep slopes, high monsoon rainfall and drought in the dry season (3).

The data were collected from both the primary and secondary sources. The primary data were collected by sample survey method through developed an interview schedule. Farmers were interviewed in groups and single mainly. The selected hillock areas from the inhabitants of Lalmai were considered for the purposes of this study although various constrained of time, money and resource personnel availability. Lalmai Uttargacha (Figure 1. a, d), Lalmai Hatigara Dakshingacha (Figure 1. c, d) and Jummura (Figure 1. $e, f$ ) were chosen for the purpose of collecting data. Total 33 farmers were selected from the villages as shown in Table 1. Interview schedule was developed based on objectives and scope of the study. The interview schedule meant for the farmers included questions on mainly hillock land utilization pattern, crop production, irrigation systems, fertilizer types and application, tillage system, input costs and returns, problems and options of the crop production systems. Before finalizing interview schedule, it was pretested on time frame, feed-back, flow of questions and answer and providing existing and new ideas by interviewing some selected farmers, scientists and resource personnel to judge the suitability of the schedule in real situation. Necessary modifications in the schedule were made on the basis of findings of the pre-testing. The modified interview schedule was printed for use the collecting necessary information. 
Field interview in the selected study areas were carried out by the scientists as well as research investigators (Figure 1). For in depth learning, this study was discussed with resource personnel of Department of Agriculture Extension, Bangladesh Agricultural Research Institute (BARI), Bangladesh Academy for Rural Development (BARD) and local peoples. Data were collected from November 2013 to February 2014. In this study, all operation costs involved in the production of each crop in a season were aggregated and valued separately to get the total production cost. Total fixed cost was not included in this study. Market rates were used for the valuation of inputs and outputs of all crops produced.
Output value was estimated on the basis of the values of output which farmers disclosed at the time of interview. Benefit cost ratio (BCR) was calculated by the ratio of gross return and input variable costs. Unit production cost was calculated by the ratio of input variable costs and total yield and it was expressed by $\mathrm{Tk} \mathrm{kg}^{-1}$ as reported. Data were compiled and subjected to mean, standard deviation (SD) and analysis of co-efficient of variance (CV) using Microsoft Excel after completing the field work and receiving all information in hands. The co-efficient of variation and standard deviation were done to justify the meaningful results.
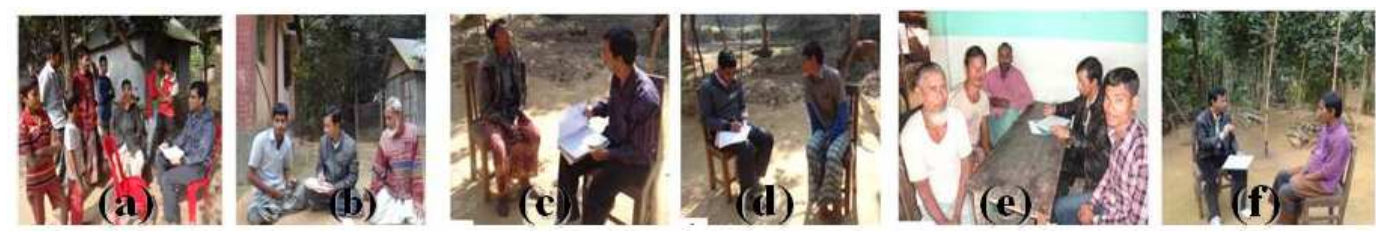

Figure 1. Data collection through interview schedule method at the study areas (a, b: Lalmai Uttachgacha, c, d: Hatigara Daskhingacha, e, f: Jummura) of Lalmai hillock region of Comilla

Table 1. Selection of villages and study samples

\begin{tabular}{llcc}
\hline \multirow{2}{*}{ S1. No. } & Study Area & No. of Farmers & Total Farmers \\
\cline { 2 - 3 } & Name of village & 13 & 33 \\
01 & Lalmai Uttargacha & 11 & 33 \\
03 & Hatigara Daskhingacha & 9 & \\
\hline
\end{tabular}

\section{Results and Discussion}

The findings of the crop production systems and economic analysis in this study were consented or supported by the related others research findings directly or indirectly from different locations and climatic conditions $(2-3 ; 7 ; 8)$.

\subsection{Weather Status}

The weather data in the field study area throughout the growing season in years of 2012 and 2013 was observed (Figure 2). Monthly precipitation ranges from 0 to $394.81 \mathrm{~mm}$. Maximum rainfall is received during the months from May to July. Rainfall during this period is excessive which leads to run-off surplus water from higher land resulting inundation and soil erosion in lower land. Winter season rains are rare. Monthly maximum and minimum air temperature ranges from $24.64^{\circ} \mathrm{C}$ to $33.15^{\circ} \mathrm{C}$ and $11.87^{\circ} \mathrm{C}$ to $26.77^{\circ} \mathrm{C}$, respectively. The mean maximum and minimum air temperature was observed $30.8^{\circ} \mathrm{C}$ and $21.4^{\circ} \mathrm{C}$, respectively. The mean maximum and minimum relative humidity was about 90.8 percent and 64.99 percent during the year, respectively and the mean minimum relative humidity was observed at the month of February. Figure 2 indicates that drought generally occurs during the period from September to May when the rainfall is scanty causing instability and insecurity to agricultural economy of the country.

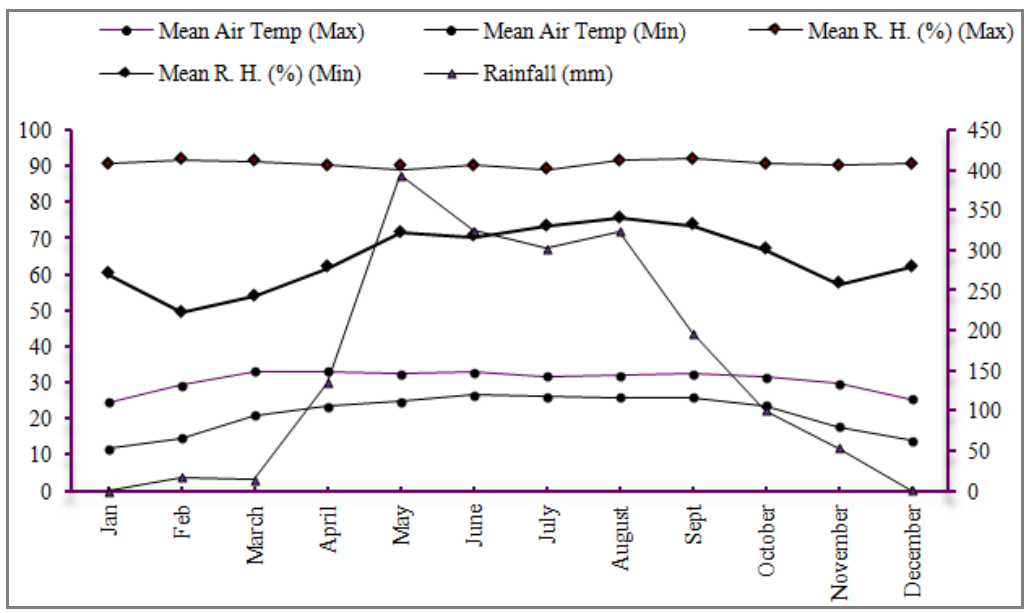

Figure 2. Weather Information at the study area 


\subsection{Cropping Pattern}

The existing cropping pattern of the study area is shown in Figure 3. The Figure 3 shows that utilization pattern of different crops were different in villages of the study area. It was found that out of 33 households so far practiced different patterns in the study areas, most farmers practiced fallow-country bean cropping sequences on the top of hillock. In valley, the most practiced crops were bitter gourd, cucumber, country bean followed by fallow - bitter gourd country bean; fallow - cucumber - country bean; long bean fallow - country bean; Transplanted Aus (T. Aus) - country bean - potato and Transplanted Aman (T. Aman) - country bean - boro rice. This indicated that the cropping pattern in the study area had some diversity. The other crops were observed matos, turmeric. Most of the lands at Lalmai hillocks are doubled cropped. A few plain lands in the valleys are tripled cropped. A few shallow tubewells have been installed at several locations only for paddy cultivation. A number of cropping patterns are existence in the study area which is mostly practiced under rainfed conditions due to shortage of supplemental irrigation and lack of irrigation facilities. Vegetable cultivation is totally rain-fed at the hillock areas. Vegetables are grown on summer and lands remain fallow for next months. The most cropping pattern was reflected in the utilization pattern of fallow - country bean which had been used only as production purposes. Matos, country bean are grown mainly on hill slopes and hill tops. Other vegetables are grown mostly in valleys. Bitter gourd, snake gourd, bottle gourd and long bean are grown on bamboo framework. The vegetables cultivation starts around mid April and in August. About $40 \%$ farmers were cultivated bitter gourd and long bean at the study areas of Lalmai hillock region. It could be said that farmer's response variety was not found high yielding variety (7). During the rabi season the crops are grown in residual soil moisture or by irrigation. During the kharif season the moisture supply from rainfall. Cropping systems, changes in production technology and the economic conditions to the hillock area has found lower to the outside of the hillock. The farmers of the study area have no clear perceptions about natural conditions including land type, cropping patterns and water management. They use traditional knowledge to decide when and which crop will be grown during the year, so that they cannot proper use their resources technology to optimize crop management and get best results.

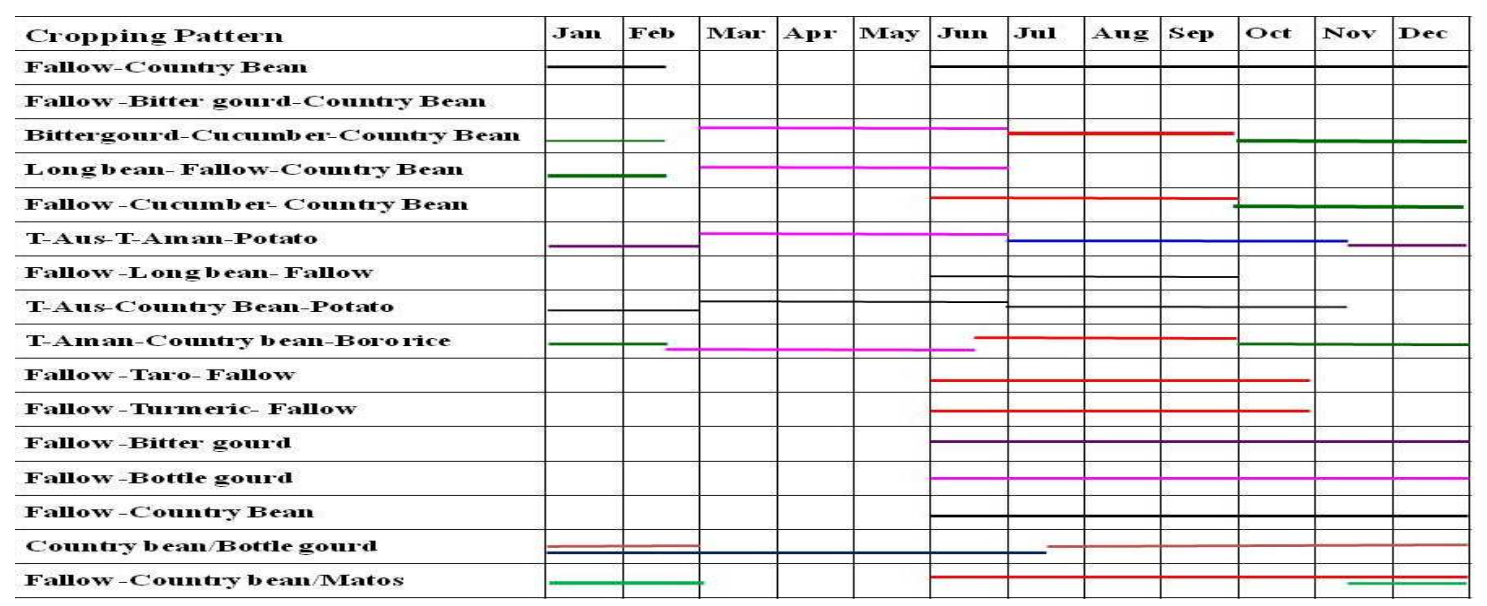

Figure 3. Existing cropping pattern at the study areas

Table 2. Benefit cost ratio and unit production cost of the existing different crops in the study area

\begin{tabular}{|c|c|c|c|c|c|c|c|c|c|c|}
\hline \multirow{2}{*}{ Crops } & \multicolumn{2}{|c|}{ Variable Cost (Tk ha-1) } & \multicolumn{4}{|c|}{ Yield (Tk ha-1) } & \multirow{2}{*}{$\begin{array}{l}{ }^{*} \text { GR } \\
\text { (Tk ha-1) }\end{array}$} & \multirow{2}{*}{$\begin{array}{l}{ }^{*} \text { GM } \\
\text { (Tk ha-1) }\end{array}$} & \multirow{2}{*}{${ }^{\mathrm{a}} \mathbf{B C R}$} & \multirow{2}{*}{$\begin{array}{l}{ }^{\mathrm{b}} \mathrm{UPC} \\
\text { (Tk kg-1) }\end{array}$} \\
\hline & Mean & SD & CV (\%) & Mean & SD & CV (\%) & & & & \\
\hline Bitter gourd & $1,77,965$ & 10933.2 & 6.14 & $13,420.7$ & 968.6 & 7.22 & $3,08,676$ & $1,30,710$ & 1.73 & 13.26 \\
\hline Bottle gourd & 94,498 & 3666.5 & 3.88 & 11158.9 & 898.0 & 8.05 & $2,23,178$ & $1,28,679$ & 2.36 & 8.45 \\
\hline Country bean & $1,30,432$ & 10,614 & & 13315 & 784 & 5.89 & $2,92,934$ & $1,62,502$ & 2.25 & 9.78 \\
\hline Cucumber & $1,69,351$ & $6,377.7$ & 3.77 & 11809.5 & 1036.2 & 8.77 & $2,36,190$ & 66,838 & 1.39 & 14.34 \\
\hline Taro & $3,25,504$ & 21001 & 6.45 & 32,246 & 4809 & 14.91 & $4,03,075$ & 77,571 & 1.24 & 10.09 \\
\hline Turmeric & $1,08,846.5$ & 3257.6 & 2.99 & $15,259.5$ & 827.0 & 5.42 & $1,52,595$ & 43,748 & 1.40 & 7.13 \\
\hline Potato & $1,36,929$ & 12,884 & 9.41 & 23443.6 & 2192.7 & 9.35 & $2,34,436$ & 97,506 & 1.71 & 5.84 \\
\hline Long bean & $2,07,595$ & $12,595.5$ & 6.08 & $14,820.4$ & 1559.4 & 10.52 & $2,96,408$ & $88,812.9$ & 1.43 & 14.01 \\
\hline Matos & 78,464 & 5268.9 & 6.72 & 6857.9 & 478.7 & 6.98 & $1,16,584$ & 38,120 & 1.49 & 11.44 \\
\hline Boro Rice & $1,02,719$ & 5119 & 4.9 & 6203.4 & 168.49 & 2.72 & $1,08559.5$ & $5,840.5$ & 1.06 & 16.56 \\
\hline T. Aman & 71,128 & 3,517 & 4. 94 & 5242.4 & 203.45 & 3.88 & 91,742 & 20,614 & 1.29 & 13.57 \\
\hline T. Aus & 78,982 & 2756.9 & 3.49 & 5177.5 & 122.3 & 2.36 & 90,606 & 11,624 & 1.15 & 15.25 \\
\hline
\end{tabular}

${ }^{\mathrm{a} B C R}$ means benefit cost ratio. Total fixed cost was not included in this study, Local market price rate was considered. ${ }^{\mathrm{b}} \mathrm{UPC}$ means unit production cost. *GR and GM mean gross return and gross margin, respectively. 


\subsection{Cost Effectiveness}

Costs of production of different crops are measured on the basis of variable input cost. Variable cost included human labor, ploughing, seeds, fertilizer, pesticides, irrigation and land lease. Among the cost items, human labors were higher in producing all types of agriculture crop production. It was found that unit production cost was found higher to the crop of boro rice than other existing crops (Table 2). But there was no more difference among the cultivation of boro, $\mathrm{T}$. Aman and T. Aus rice. Bottle gourd is more profitable (Table 2) but farmers were not interested to invest more money due to severe yellow mosaic virus. The highest gross margin obtained from country bean followed by others crops. It indicated that the variation of obtaining gross margin from associated within the efficiency of inputs use at the field level. The variation of the BCR was counted from the range of 1.43 to 1.95 (Table 3). The results indicated that BCR was found higher in the cropping pattern of fallow-bitter gourd-country bean than other existing cropping pattern of the study areas (Table 3). The lowest BCR was observed from the one crop per year. The variation of the results indicated that farmers are very interested to produce more crop through invest more money for the highest coverage and utilization of the hillock areas. Sarker et al. (8) also stated that the highest BCR was observed (2.5) in the cropping pattern of wheat - Jute - T. Aman and the lowest BCR was observed (1.75) in the cropping pattern of Potato Maize - T. Aman of northwest region in Bangladesh.

Cultivation of the relay cropping method is the most common cropping pattern in the hillock area. Vegetable cultivation with relay cropping method is the most economical cropping pattern (Table 4). The consecutive crops are country bean + bottle gourd and country bean + matos. The relay cropping method of country bean + bottle gourd was observed more profitable than the country bean + matos.

Table 3. Benefit cost ratio (BCR) of the existing cropping pattern per year in the study area

\begin{tabular}{|c|c|c|c|c|}
\hline Cropping Pattern & $\mathrm{VC}\left(\mathrm{Tk} \mathrm{ha}^{-1}\right)$ & GR $\left(\right.$ Tk ha $\left.^{-1}\right)$ & GM $\left(\mathrm{Tk} \mathrm{ha}^{-1}\right)$ & $\overline{\text { BCR }}$ \\
\hline Fallow - Bitter gourd - Country bean & $3,08,397.5$ & $6,01,610.5$ & $2,93,212.4$ & 1.95 \\
\hline Bitter gourd - Cucumber - Country bean & $3,94,282.0$ & $7,52,302.4$ & $3,58,020.4$ & 1.91 \\
\hline Long bean - Fallow - Country Bean & $3,38,027.01$ & $5,89,342.4$ & $2,51,315.4$ & 1.74 \\
\hline Fallow - Cucumber - Country Bean & $2,99,783.3$ & $5,29,124.4$ & $2,29,341.1$ & 1.77 \\
\hline T. Aus - T. Aman - Potato & $2,87,039.07$ & $4,16,784.3$ & $1,29,745.23$ & 1.45 \\
\hline Fallow - Long bean - Fallow & $2,07,595.01$ & $2,96,408.0$ & $88,812.99$ & 1.43 \\
\hline T. Aus - Country bean - Potato & $3,46,343.07$ & $6,17,976.7$ & $2,71,633.63$ & 1.78 \\
\hline T. Aman- Country bean - Boro rice & $3,04,279.0$ & $4,93,235.9$ & $1,88,956.9$ & 1.62 \\
\hline
\end{tabular}

Note: VC, GR and GM means variable cost, gross return and gross margin, respectively. Total fixed cost was not included in this study.

Table 4. Benefit cost ratio analysis of the vegetable cultivation with relay crops for in the study areas

\begin{tabular}{|c|c|c|c|c|}
\hline Relay Crops & $\mathrm{VC}\left(\mathrm{Tk} \mathrm{ha}^{-1}\right)$ & GR $\left(\mathrm{Tk} \mathrm{ha}^{-1}\right)$ & GM $\left(\mathrm{Tk} \mathrm{ha}^{-1}\right)$ & BCR \\
\hline Country bean / Bottle gourd & $2,24,930.7$ & $5,16,112.4$ & $2,91,181.7$ & 2.29 \\
\hline Fallow -Country Bean/ Matos & $2,08,896$ & $4,09,518.7$ & 200622.7 & 1.96 \\
\hline
\end{tabular}

Note: VC, GR and GM means variable cost, gross return and gross margin, respectively. Total fixed cost was not included in this study

\subsection{General Problems and Future Options}

\subsubsection{General Problems}
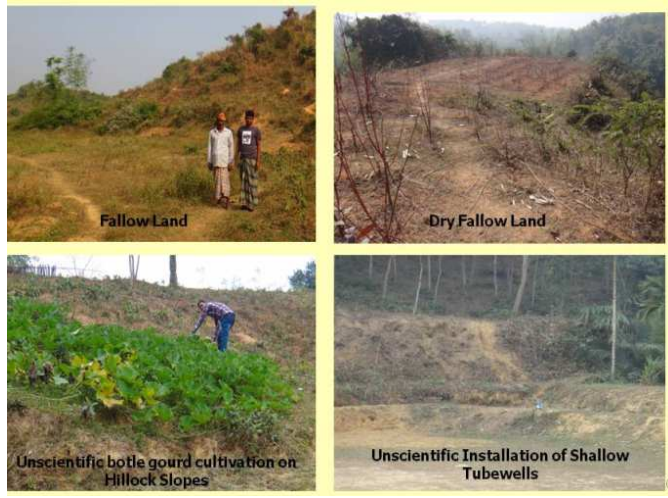

Figure 4. Unscientific crop cultivatin at hillockarea of Lalmai region

Some general problems were observed as follows:

- The functional gap among the village farmers, researchers and extensionist at hillock areas.

- Unscientific cultivation on the slopes and valleys without following terrace method is caused tremendous of soil erosion and silting (Figure 4).

- The adoption of high yielding varieties is still limited.

- Crop production in any hillock area that is affected by drought and sudden heavy rainfall. No rainfall in winter season.

- Irrigation is the great problem at the hillock region. The farmers are not using irrigation technology with other agriculture practices for improving crop production.

- Quality seed crisis acute during sowing

- Lack of transportation and marketing system

- Uncontrolled plant diseases and insect pests.

\subsubsection{Future Options}

Based on this study, the future options/guidelines can be comprised as:

- To address this concept of the idea, further research could be planned on agriculture crop production systems.

- Using quality agriculture inputs such as seeds, fertilizers, pesticides, farm equipment and irrigation facilities should be available. 
- Cultivation of hybrid crop varieties can be promoted at this study area. To cope with the annual variation in crop productions, it is recommended that high yielding varieties may introduce at the study area.

- Crop diversification and intensification along with multiple and mixed cropping systems may generate more income for the small scale farmers.

- Drought resistance crops and crops requiring light irrigation are suggested for cultivation because of the doughtiness of the study area during winter season.

- Matching current crop varieties and cropping systems to likely shifts in rainfall and temperature regimes; this is predicated on a better understanding of climate variability and the access to reliable seasonal climate forecasts.

- Overhead tank systems for sprinkler, drip or fertigation system could be installed for irrigation during dry season.

- Farmers can conserve rainwater by farm ponds, jalkund and small reservoir for agricultural crops during rabi season (5).

- Supplementary irrigation would help to reduce the risk of crop production. Supplementary irrigation can be sourced from water harvesting. Rainwater harvesting is proved to be very helpful for water and energy conservation by assessing the water use efficiency (WUE) and energy consumption for agriculture crop production (9).

- Terrace cultivation system at different heights of the hillock could be introduced and made popular. Some crops should be grown on middle slopes.

- Government and Non-government interventions are also necessary to provide credit, training and other essential inputs to local farmers. An adequate extension service along with credit facilities is needed to motivate farmers to increase the cropping intensity.

- Local organizations may help to promote land use, soil management, vegetable cultivation and diversification of the economy through farmer's participation.

- Long term study for overall development of the Lalmai hillock agriculture systems including economical and environmental may be undertaken.

- More efforts and long-term study would be needed to evaluate and improve the new approach on hillock agricultural systems to achieve and attract the farmers for sustainable agriculture adoption.

\section{Conclusion}

Based on the study, the following conclusion can be drawn.

- After analyzing of the hillock crop production system it was found that most of the farmers practiced fallow-country bean cropping sequences on the top of hillock.

- The unit production cost of the potato was lowest as compared to other crops. The benefit cost ratio of the bottle gourd was observed higher than other existing crops.

- The benefit cost ratio of the cucumber, turmeric and long bean was observed almost similar.

- The benefit cost ratio of the existing cropping pattern per year in the study area was counted from the range of 1.43 to 1.95 . The BCR was found more in the cropping pattern of fallow + bitter gourd + country bean than other existing cropping pattern of the study areas. The lowest BCR was observed from the one crop per year.

- Vegetable cultivation with relay cropping method is the most economical cropping pattern. The consecutive crops are country bean + bottle gourd, country bean + matos and the BCR was found 2.29 and 1.96 , respectively.

However, Lalmai hillock area is emerging as one of the prominent vegetable areas of the country. Therefore, the efforts are necessary to utilize the potentials of Lalmai hillock areas for greater economic returns. The proper implementation of the agriculture crop production system at the hillock region may bring positive changes in the economy of the country.

\section{Acknowledgements}

The authors would like to thanks Bangladesh Agricultural Research Council, Bangladesh Academy for Rural Development, Bangladesh Agricultural Research Institute for their helps, providing all facilities, and sharing their expertise for sustainable crop production systems.

\section{References}

[1] Jaim, W. M. H., "Agricultural Development in Bangladesh: Views \& Reviews". Joint Study on Rural Development Experiment, Bangladesh Academy for Rural Development (BARD), Kotbari, Comilla. Japan International Co-operation Agency (JICA), Dhaka, Bangladesh, 1995.

[2] Roy, K. M., and S. K., Munshi, "Hill Agriculture: A Socio-Economic Analysis". Bangladesh Academy for Rural Development (BARD), Kotbari, Comilla, 2006

[3] Alam, M.N. and M., Ahmed, "Role of ICT in ARD: Status Report of Bangladesh". Bangladesh Agricultural Research Council, Farmgate, Dhaka 1215, Bangladesh, 2000.

[4] Solaiman, M., T. R., Bose, M. K., Bhattacharjee, and Q. A.. Kabir, "Lalmai Hills: Potentials and Problems". Bangladesh Academy for Rural Development (BARD), Kotbari, Comilla, 2000

[5] Ansari, M. A., N., Prakash, L.K., Baishya, P., Punitha, J.S., Yadav, P. K., Sharma, B., Sailo, and M. H Ansari, "Comparative study on conventional and improved integrated farming systems for sustainable production, income generation and employment opportunity among the tribal farmers in hilly Regions of Manipur". Indian Journal of Agricultural Sciences, 83 (7): 765-772, 2013 
[6] Yadav, G.S., Debnath, C., Datta, M., Ngachan, S.V., Yadav, J. S., Babu, "Comparative evaluation of traditional and improved farming practices in Tripura". The Indian Journal of Agricultural Sciences, Vol. 83. No 3, 2013.

[7] BARI (Bangladesh Agricultural Research Institute), "Agriculture Production Technology Hand Book, BARI Annual Report, Gazipur”, 2014

[8] Sarker, M.A.Z., M.A., Alam, A., Hossain, and M.A.,
Mannaf, "Agro-economic performance of crop diversification in rice based cropping systems of northwest Bangladesh". Agriculture, Forestry and Fisheries, 3(4): 264-270, 2014.

[9] Jang, Z. Y., Li, X. Y., Ma, and Y. J., "Water and Energy Conservation of Rainwater Harvesting System in the Loess Plateau of China”. Journal of Integrative Agriculture, 12(8): 1389-1395, 2013. 